\title{
Revegetation of Rock Slopes with Different Substrates in an Abandoned Quarry in Jinju, Korea
}

\author{
Ma Hoseop ${ }^{1}$, Ettagbor Hans Enukwa ${ }^{1}$, Kang Wonseok ${ }^{2} \&$ Kim Choonsig $^{3}$ \\ ${ }^{1}$ Department of Forest Environmental Resources, Gyeongsang National University (Institute of Agriculture and \\ Llife Science), Korea \\ ${ }^{2}$ Forest Restoration Division, National Institute of Forest Science, Korea \\ ${ }^{3}$ Department of Forest Resources, Gyeongnam National University of Science and Technology, Korea \\ Correspondence: Ma Ho-Seop, Department of Forest Environmental Resources, Gyeongsang National \\ University, Jinju 528-28, Korea. Tel: 82-055-772-1851. E-mail: mhs@gnu.ac.kr
}

Received: May 24, 2016

doi:10.5539/jgg.v8n3p26
Accepted: June 20, 2016

Online Published: August 20, 2016

URL: http://dx.doi.org/10.5539/jgg.v8n3p26

\begin{abstract}
The purpose of this research was to investigate the use of drilled slanted holes filled with different substrates in the revegetation of rock slopes. Slanted holes were drilled on rock slopes using pneumatic drillers in an abandoned limestone quarry area. These holes were filled with twelve different substrates, treated with Trichoderma harzianum. One climbing plant of Ivy (Hedera rhombea), a native woody plant (Lespedeza cyrtobotrya), three native herbaceous plants (Dianthus barbatus, Siberian chrysanthemum and Aster koraiensis) and one exotic grass plant (Festuca arundinacea) were planted in each of the soils. Six months after planting, only Ivy, Festuca arundinacea, Lespedeza cyrtobotrya and Dianthus barbatus were still observed growing on the soils, while the other plant species had already died in all the 12 soil treatments. Leaf mold soil $+50 \%$ Trichoderma harzianum provide the best conditions for revegetation of Festuca arundinacea, as this plant had its highest mean height, high survival rate, with impressive growth rate on this soil. Lespedeza cyrtobotrya also had its most favorable growth on Leaf mold soil $+50 \%$ T. harzianum. Mixed soil $+100 \%$ T. harzianum provide the best conditions for revegetation of Ivy. Leaf mold soil $+100 \% T$. harzianum provide the best condition for revegetation of Dianthus barbatus as it had its highest mean height, highest growth rate and high survival rate on this soil. Siberian chrysanthemum and Aster koraiensis had the worse results as all of the plants died within a short period of time after planting. Ivy had the highest mean height, followed by Festuca arundinacea. The planted Ivy and Festuca arundinacea now form the vegetation of the research site which together with the substrate is now providing habitat to some wildlife like some species of centipedes, earthworms, insects and wild plants. Less than one year after planting, $F$. arundinacea already produced flowers and seeds which would further increase the plant population after dispersal and germination. Drilling slanted holes on rock slopes is therefore a feasible method to be used for revegetation and restoration of degraded quarries.
\end{abstract}

The revegetation of steep rock slopes of quarries is a very challenging activity. However, the method of drilling slanted holes on rock slopes is a feasible method to be used for restoration of degraded quarries. These holes could serve in soil deposition and water retention that will further enhance plant growth.

Methods of improving seed germination as well as enhancing growth of plants are also imperative in revegetation success of such degraded landscapes. Different percentage mixtures of $T$. harzianum in different soils could enhance plant growth depending on the target plant species. Different substrates could thus be used in such revegetation process depending on the target plant species.

Revegetation would provide habitat and improve landscape beauty and stability, thus it is important for successful restoration of rock slopes

Keywords: drilled holes, landscape restoration, soil treatment, survival rate, quarry, Trichoderma harzianum

\section{Introduction}

The exploitation of quarry areas to obtain construction materials is a common phenomenon all over the world. The earthworks in the exploitation process generally leave the quarry areas with numerous steep slopes (Zhong et al., 2009), and renders the site barren due to vegetation removal and soil profile destruction (Hao \& Chu, 
2011). Lack of rehabilitation in such quarries, leaves extensive and unsightly scars on the landscape, as well as increase in soil erosion and physical safety hazards (Jim, 2011). Natural succession is usually a very slow process in such damaged landscapes, giving the need for artificial revegetation as an imperative option.

The presence of tall vertical rock faces that have little soil or water poses a major difficulty of quarry rehabilitation (Jim, 2001). Also, restoring quarry areas is a major challenge due to drawbacks such as soil loss and modification/alteration of the original topography (Clemente et al., 2004), thus necessitating the use of additional substrates that will enhance plant growth for restoration of the landscape (Oliveira et al., 2011). Methods of improving seed germination as well as enhancing growth of plants are therefore imperative in revegetation of such degraded landscapes.

Soil replacement by a low quality substrate is often inadequate for revegetation and limits plant establishment and growth in degraded areas (Oliveira et al., 2011). The use of high quality substrate is imperative for revegetation of quarry areas.

The concept and methods of treating potting soil with beneficial organisms to enhance healthy seed germination and plant growth has developed to be a common practice in recent years. Trichoderma innoculants have been increasingly used in recent years as such beneficial organisms. The application of Trichoderma innoculants in potting soil increases considerably the germination and growth rate of plants (Zuoxing, 1999). Trichoderma species are widely used in agriculture as biological control agents against plant pathogenic organisms that cause many plant root diseases (Adams, 1990; Andrews, 1992). The wide use of Trichoderma species as biological control agents is due to its ability to mitigate competition for soil nutrients and space (Elad, 1996), its potential to produce antibiotic substances (Vinale et al., 2006) and its potential to improve resistance to pathogens (Chandra et al., 2010). Trichoderma harzianum is an effective biological control agent against a variety of plant pathogens (Ferrigo et al., 2014). T. harzianum is the most widely used of the Trichoderma species due to its high ability to foster/enhance plant growth (Akladious \& Abbas, 2014), following its potential to colonize plant roots in different soil types (Harman \& Bjorkman, 1998). However, there is limited documentation on the growth enhancement capacity of $T$. harzianum using different percentage mixtures in varied soils.

We hypothesize that $T$. harzianum in different soils respond differently in enhancing plant growth. Drilling slanted holes on rock slopes is feasible method for revegetation of rock slopes.

This research therefore aimed at investigating the response of different plant species to different substrate treatments, to ascertain which substrate treatment and plant species could be preferably used in the restoration of this degraded quarry. T. harzianum was used in different quantities to treat the four different soils used in this experiment.

\section{Materials and Methods}

\subsection{Site description}

The trial was a pilot test to determine the revegetation method that would work for the site. The site is an exploited and abandoned quarry, with steep rock slopes (Fig. 1), having scanty vegetation cover in some areas and no vegetation at all in others. No restoration of the area has been carried out as the slopes are made principally of parent rock with soil deficiency, limiting vegetation growth.

\subsection{Soil Preparation, Soil Characteristics and Target Species}

Four different soils were used for this experiment including: 1. Brown Forest soil obtained from a thick forest in the Jinju area; 2. Leaf mold soil consisting of a mixture of fermented coco peat and decomposed leaves; 3. Merchantable soil with weathered granite, consisting of a mixture of fermented coco peat, vermiculite, perlite and nutrient solution; 4. Mixed soil composed of a proportionate mixture of soils one, two and three above. Each of the four soil types were further divided into three samples. The first sample was mixed with the microorganism Trichoderma. harzianum at a ratio of $100 \%$ i.e. $10 \mathrm{~g}$ of $T$. harzianum per $\mathrm{Kg}$ of soil. The second sample was mixed with $T$. harzianum at the ratio of $50 \%$ i.e. $5 \mathrm{~g}$ of $T$. harzianum per $\mathrm{Kg}$ of soil. The third sample was the control consisting of the soil having no microorganism treatment. Each of the treated samples had a second repetition, thus 6 samples for each of the four soil types.

Physicochemical analysis of the soils showed that Forest soil had the highest $\mathrm{pH}$ of 6.15 , while Leaf mold soil had the lowest $\mathrm{pH}$ of 5.57. For Electrical conductivity, Leaf mold soil had the highest of $13.86 \mathrm{dS} / \mathrm{m}$, merchantable soil had $8.12 \mathrm{dS} / \mathrm{m}$, while Forest soil had $0.53 \mathrm{dS} / \mathrm{m}$. Leaf mold soil had the highest soil organic matter content of $20.175 \%$, while Forest soil had the lowest of 5.214\%. For total nitrogen content, Leaf mold soil had $12.71 \%$, Merchantable soil had $7.72 \%$, while Forest soil had the lowest of $0.37 \%$. Available phosphorus content for Leaf mold soil (204.93 mg/Kg), Merchantable soil (103.91 mg/Kg), Mixed soil $(68.12 \mathrm{mg} / \mathrm{Kg})$, 
Forest soil (7.96 mg/Kg). Among the cations, $\mathrm{Ca}, \mathrm{Mg}, \mathrm{K}, \mathrm{Na}$ contents were higher in Leaf mold soil and smallest in Forest soil.

The selection of plants for use in this experiment was based on two criteria: first, known to exhibit favorable growth in the Jinju area; second, good stress resistance. Thus, one climbing plant (Ivy), a native woody plant (Lespedeza cyrtobotrya), three native herbaceous plants (Dianthus barbatus, Siberian chrysanthemum and Aster koraiensis) and one exotic grass plant (Festuca arundinacea) were selected and used for the experiment. All six plant species were planted in each of the 24 holes.

\subsection{Field Experiment}

Considering the challenges associated with the use of the common revegetation procedure for high and steep rock slopes, which involves reducing the slope angle by blasting and using the debris to build an artificial and gentler slope or platform, followed by covering top soil, then planting seeds (Clemente et al., 2004), in this study, we used an innovative and less challenging method that involves drilling slanted vertical holes on rocky slope surfaces using pneumatic drillers, filling the holes with potting sacs filled with soil and planted seeds and seedlings (Zhong et al., 2009).

In June 2015, artificial holes with diameter of $10 \mathrm{~cm}$ and depth of $20 \mathrm{~cm}$ were drilled on the rock slope surfaces (Figure 1). The holes were arranged in grids with horizontal distance between holes of $1 \mathrm{~m}$ and vertical distance of $1 \mathrm{~m}$. A total of 24 holes were drilled along the quarry surfaces. The holes were filled with soils put in potting sacs of $10 \mathrm{~cm}$ by $20 \mathrm{~cm}$ with identified tags. All plant species were planted in each of the 24 potting sacs. 20 seeds of five of the plant species (excluding Ivy) were planted in each potting sac and two Ivy seedlings i.e. a total of 100 seeds and two germinating Ivy plants were planted in each of the potting sacs. The planting of too many seed plants in each potting sac was to enable overcrowding, so as to ensure a high rate of competition by the plants. Survival of the fittest would therefore occur, and the most resistant plants would dominate. Watering of the soil was done for two weeks after planting, after which, the plants were allowed to grow without watering, in the natural environmental conditions of the experimental site. The plants were allowed to grow in the summer, autumn and winter seasons, so as to ascertain their adaptability to the area.
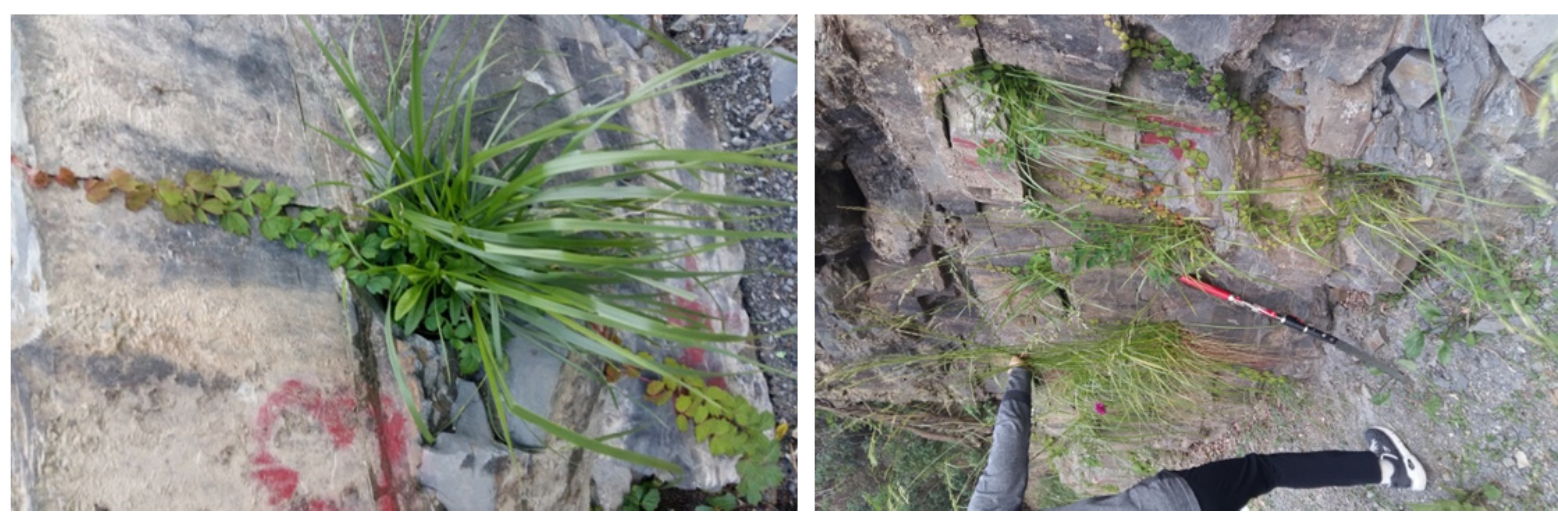

Figure 1. Drilled holes on rock slope filled with soil on which plant growth is enhanced. Ivy and Festuca arundinacea have favourable growth, with Festuca arundinacea already producing seeds one year after planting

\subsection{Data Collection and Statistical Analysis}

The seed germination was recorded regularly, and the germination criterion was the appearance of the seed cotyledon. Survival rate was calculated by counting the number of each plant in each soil treatment on the $12^{\text {th }}$ week $\left(26^{\text {th }}\right.$ August, 2015) after planting, since by this time, the plants are well established and this period is characterized by hot temperatures and some rainfall. Counting of each plant species that had survived and those that had died was therefore done by the $26^{\text {th }}$ week $\left(07^{\text {th }}\right.$ December, 2015 , winter period) and the survival rates were then calculated for the period in relation to the number of

Table 1. Survival rate (\%) of four plant species on twelve soil treatments 


\begin{tabular}{|c|c|c|c|c|c|}
\hline \multirow[b]{2}{*}{ Soil Treatment } & \multicolumn{5}{|c|}{ Survival rate $(\%)$} \\
\hline & $\begin{array}{l}\text { Dianthus } \\
(\%) \\
\end{array}$ & barbatus & $\begin{array}{l}\text { Festuca arundinacea } \\
(\%)\end{array}$ & $\begin{array}{l}\text { Lespedeza } \\
\text { cyrtobotrya (\%) }\end{array}$ & Ivy $(\%)$ \\
\hline Forest soil $+100 \% \mathrm{~T}$. harzianum & 0 & & 100 & 0 & 75 \\
\hline Forest soil $+50 \% \mathrm{~T}$. harzianum & 50 & & 100 & 100 & 100 \\
\hline Forest soil $+0 \% \mathrm{~T}$. harzianum & 0 & & 100 & 100 & 50 \\
\hline Mixed soil $+100 \% \mathrm{~T}$. harzianum & 0 & & 100 & 0 & 75 \\
\hline Mixed soil + 50\% T. harzianum & 0 & & 0 & 0 & 75 \\
\hline Mixed soil $+0 \% \mathrm{~T}$. harzianum & 100 & & 87.5 & 0 & 20 \\
\hline Merchantable soil $+100 \% \mathrm{~T}$. harzianum & 0 & & 100 & 0 & 50 \\
\hline Merchantable soil $+50 \% \mathrm{~T}$. harzianum & 0 & & 100 & 0 & 100 \\
\hline Merchantable soil $+0 \% \mathrm{~T}$. harzianum & 0 & & 100 & 0 & 100 \\
\hline Leaf mold soil + $100 \% \mathrm{~T}$. harzianum & 100 & & 100 & 0 & 100 \\
\hline Leaf mold soil $+50 \% \mathrm{~T}$. harzianum & 50 & & 100 & 50 & 66.67 \\
\hline Leaf mold soil $+0 \% \mathrm{~T}$. harzianum & 0 & & 100 & 50 & 100 \\
\hline
\end{tabular}

each plant species recorded on the $12^{\text {th }}$ week. Dead plants were those that were leafless with visibly dry stems. Measurement of stem length was done by measuring the distance from the soil of the hole to the apical bud of the concerned plant. The monthly relative growth rates (RGR) was calculated as follows:

$$
\left.\mathrm{RGR} \%=\frac{(\mathrm{Mf} / \mathrm{Mi}}{\Delta \mathrm{T}}-0.05\right) \times 100
$$

Table 2. Relative growth rate (\%) of four plant species on twelve soil treatments

\begin{tabular}{|c|c|c|c|c|}
\hline \multirow[b]{2}{*}{ Soil Treatment } & \multicolumn{4}{|c|}{ Relative growth rate (RGR) \% } \\
\hline & Dianthus barbatus $(\%)$ & Festuca arundinacea $(\%)$ & Lespedeza cyrtobotrya $(\%)$ & Ivy $(\%)$ \\
\hline Forest soil $+100 \% \mathrm{~T}$. harzianum & 0 & 32 & 0 & 48.5 \\
\hline Forest soil $+50 \% \mathrm{~T}$. harzianum & 23.6 & 29.8 & 33 & 45.8 \\
\hline Forest soil $+0 \% \mathrm{~T}$. harzianum & 0 & 56 & 39.3 & 20.7 \\
\hline Mixed soil $+100 \%$ T. harzianum & 0 & 38 & 0 & 43 \\
\hline Mixed soil $+50 \% \mathrm{~T}$. harzianum & 0 & 0 & 0 & 61.3 \\
\hline Mixed soil $+0 \% \mathrm{~T}$. harzianum & 23.6 & 44.8 & 0 & 54.1 \\
\hline Merchantable soil $+100 \% \mathrm{~T}$. harzianum & 0 & 35.4 & 0 & 50.7 \\
\hline Merchantable soil $+50 \%$ T. harzianum & 0 & 77.2 & 0 & 30.9 \\
\hline Merchantable soil $+0 \% \mathrm{~T}$. harzianum & 0 & 25.7 & 0 & 27.3 \\
\hline Leaf mold soil $+100 \% \mathrm{~T}$. & 85.7 & 39.2 & 0 & 39.1 \\
\hline harzianum & 22.4 & 25.2 & 52 & 36.9 \\
\hline Leaf mold soil $+50 \% \mathrm{~T}$. harzianum & 0 & 39.9 & 26.2 & 24.7 \\
\hline Leaf mold soil $+0 \% \mathrm{~T}$. harzianum & & & & \\
\hline
\end{tabular}

Where Mf is the final measurement of the mean stem length $\left(07^{\text {th }}\right.$ December, 2015), Mi is the initial measurement of the mean stem length $\left(26^{\text {th }}\right.$ August, 2015), and $\Delta \mathrm{T}$ is the number of months passed between the measurements (Zammith \& Scarano, 2006; Zhong et al., 2009) corresponding to about 3.5 months.

One-way analysis of variance (ANOVA) followed by LSD Significant Difference test at $p<0.05$ was used to determine any significant difference between means of different phases. The differences in plant lengths were analyzed by using ANCOVA. Statistical significance was reported at $\mathrm{P}<0.05$. Data analysis was done with IBM SPSS Statistics 23.

The diversity index (Shannon index) of the plant community obtained in each soil treatment was calculated. To obtain the evenness of plant distribution for the given species in the community, the Shannon 's equitability $\left(\mathrm{E}_{\mathrm{H}}\right)$ was calculated by dividing $\mathrm{H}$ by Hmax (here $\mathrm{Hmax}=\mathrm{InS})$ i.e. $\mathrm{E}_{\mathrm{H}}=\mathrm{H} / \mathrm{H} \max (\mathrm{Hmax}=\mathrm{In} \mathrm{S})$

Where $\mathrm{E}_{\mathrm{H}}$ is the evenness or equitability, $\mathrm{H}$ is Shannon diversity index, Hmax is the maximum diversity possible, $\mathrm{S}$ is the number of species (species richness). Equitability assumes a value between 0 and 1 with 1 being complete evenness. 


\section{Results}

\subsection{Seed Germination in the Area}

Seed germination was a continuous process and varied from one plant species to the other. Within the first week of sowing, the counted number of plants for each species was as follows: Dianthus barbatus (87 plants), thus D. barbatus had the highest initial germination; Lespedeza cyrtobotrya (40 plants); Siberian chrysanthemum (14 plants) and Aster koraiensis (0 plant). Germination of seed plants continued after week one but it was relatively slow. Aster koraiensis did not germinate at all, indicating that it could not cope with the high competition in the soil media. Contrarily, Festuca arundinacea which had an initial low germination of 27 plants in the first week had an increase in germination from the second week, up to the fifth week that it attained its highest germination of 111 plants recorded.

\subsection{Plant Length, Survival Rates and Growth Rates}

\subsubsection{Plant Length}

The average length (mean height) of the four plant species varied from one soil treatment to another (Fig. 2). Generally, the plants had a progressive increase in height with time. However, two plant species (Siberian chrysanthemum and Aster koraiensis) had zero mean height as Aster koraiensis had no germination, while the few Siberian chrysanthemum that germinated died a few days after. By December $07^{\text {th }}, 2015$ (about 06 months after planting), Ivy had the highest mean height of $87 \mathrm{~cm}$ on Mixed soil $+100 \%$ T. harzianum. Festuca arundinacea and Lespedeza cyrtobotrya had high mean heights of over $44 \mathrm{~cm}$ and $16.5 \mathrm{~cm}$ respectively on Leaf mold soil $+50 \%$ T. harzianum. Dianthus barbatus had its highest mean height of over13cm on Leaf mold soil + $100 \%$ T. harzianum.

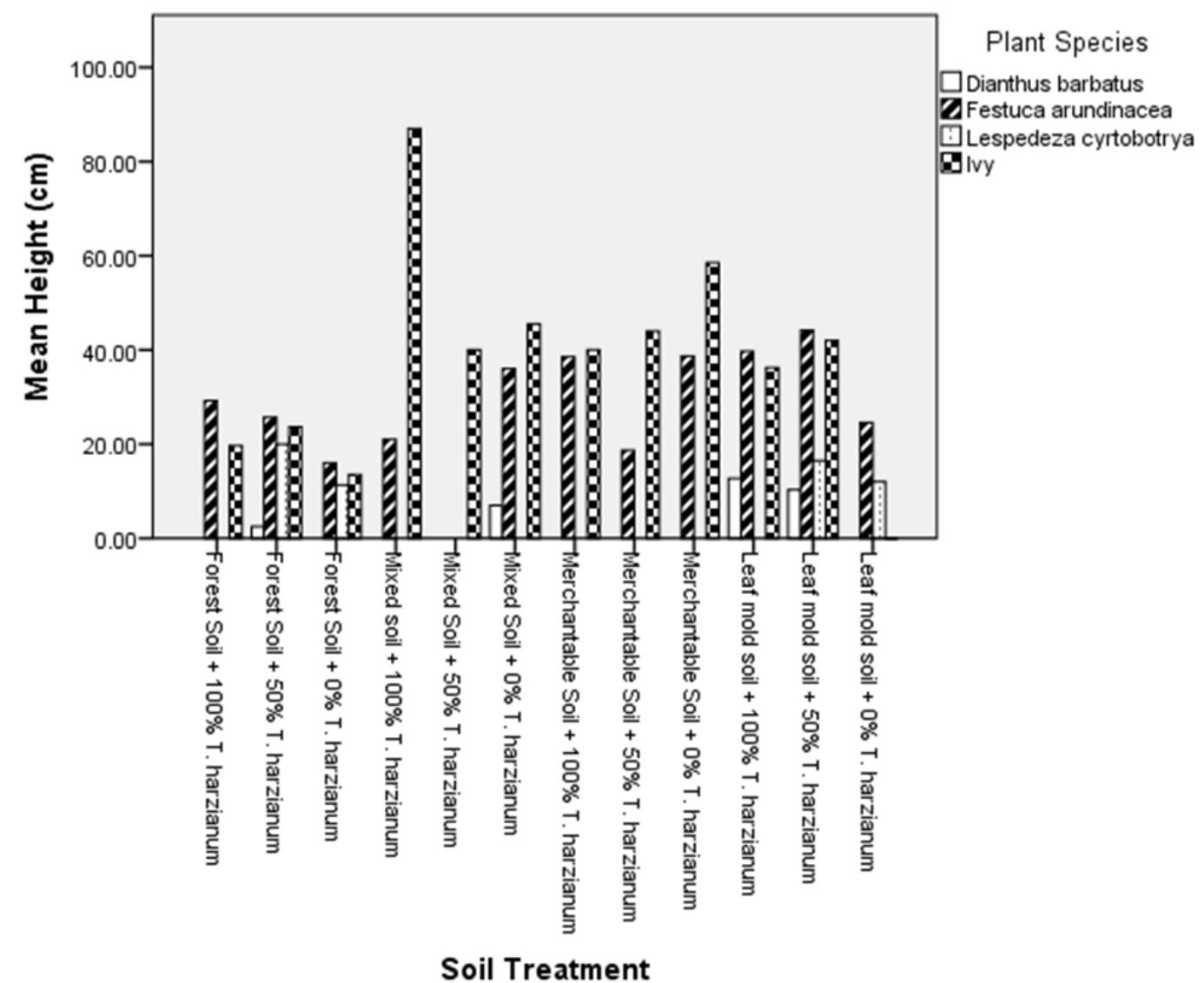

Figure 2. Growth trends of four plant species on 12 soil treatments over a period of six months $\left(06^{\text {th }}\right.$ June 2015-0 $7^{\text {th }}$ December 2015).

About one year after planting (06 ${ }^{\text {th }}$ June $2015-31^{\text {st }}$ May 2016), Ivy and Festuca arundinacea had grown much taller with $F$. arundinacea visibly producing flowers and seeds.

\subsubsection{Survival Rate and Growth Rate}

The survival rate and growth rate for each plant species was calculated for the soil treatments that the plant 
species was observed alive by the $26^{\text {th }}$ week of the study. Dianthus barbatus and Lespedeza cyrtobotrya were alive in four soil treatments each; Festuca arundinacea was alive in 11 soil treatments, while Ivy was alive in all 12 soil treatments (Table 1). Generally, the plants had high survival rates (Table 3). Ivy and F. arundinacea had the highest growth rate of over $40 \%$ (Table 4 ).

Table 3. Survival rate (\%) of 4 plant species

\begin{tabular}{ll}
\hline Plant species & Survival rate (\%) \\
\hline Dianthus barbatus & $75 \pm 14.4$ \\
Festuca arundinacea & $98.9 \pm 1.1$ \\
Lespedeza cyrtobotrya & $75 \pm 14.43$ \\
Ivy & $75.97 \pm 7.5$ \\
& $\mathrm{P}=<0.0001$ \\
\hline
\end{tabular}

The mean difference is significant at the 0.05 level by LSD test

Table 4. Growth rate (\%) of 4 plant species

\begin{tabular}{ll}
\hline Plant species & Growth rate (\%) \\
\hline Dianthus barbatus & $38.8 \pm 15.6$ \\
Festuca arundinacea & $39.4 \pm 4.6$ \\
Lespedeza cyrtobotrya & $37.6 \pm 5.5$ \\
Ivy & $40.3 \pm 3.6$ \\
& $\mathrm{P}=<0.091$ \\
\hline
\end{tabular}

\subsection{Diversity Index}

The Mixed soil $+50 \%$ Trichoderma. harzianum has evenness $\left(\mathrm{E}_{\mathrm{H}}\right)$ of 0 , as it consist of only one plant species (Ivy). The Merchantable soil $+100 \%$ T. harzianum consisting of two plant species, has a low evenness $\left(\mathrm{E}_{\mathrm{H}}\right)$ of 0.66 , as one plant species (Festuca arundinacea) makes up $83 \%$ of the plant community while Ivy makes up only $17 \%$ of the plant community on the soil.

Table 5. Distribution of four plant species on different soil treatments

\begin{tabular}{llll}
\hline Soil treatment & No. of Species & Shannon index $(\mathrm{H})$ & Evenness $\left(\mathrm{E}_{\mathrm{H}}\right)$ \\
\hline Forest soil + 100\% T. harzianum & 2 & 0.57 & 0.8 \\
Forest soil + 50\% T. harzianum & 4 & 1.19 & 0.86 \\
Forest soil + 0\% T. harzianum & 3 & 1.09 & 0.99 \\
Mixed soil + 100\% T. harzianum & 2 & 0.57 & 0.81 \\
Mixed soil + 50\% T. harzianum & 1 & 0 & 0 \\
Mixed soil + 0\% T. harzianum & 3 & 0.75 & 0.68 \\
Merchantable soil + 100\% T. harzianum & 2 & 0.46 & 0.66 \\
Merchantable soil + 50\% T. harzianum & 2 & 0.66 & 0.99 \\
Merchantable soil + 0\% T. harzianum & 2 & 0.68 & 1 \\
Leaf mold soil + 100\% T. harzianum & 3 & 1.04 & 0.95 \\
Leaf mold soil + 50\% T. harzianum & 4 & 1.06 & 0.76 \\
Leaf mold soil + 0\% T. harzianum & 3 & 0.92 & 0.84 \\
\hline
\end{tabular}

\subsection{Habitat Provision}

As plant growth continued on the drilled holes in the rock slope, wildlife species were observed over time living in the study site. This indicates that the experimental plants and soil have contributed greatly in providing habitat for the organisms. Centipedes, earthworms and insects were recorded on the study site, as well as some wild plants observed growing on the substrates.

\section{Discussion}

Many studies showed that the use of Trichoderma harzianum can significantly promote plant growth (Zuoxing, 
1999; Chowdappa et al., 2013). It is therefore necessary to ascertain the influence of T. harzianum on plant growth on different soil treatments. In the current study, the influence of $T$. harzianum on enhancing plant growth is dependent on the soil media and the target plant species. Plant length significantly varied between all soils treatments

Different percentage mixtures of $T$. harzianum in the soil respond differently in their capacity to enhance plant growth. In this study, Ivy, Festuca arundinacea, Dianthus barbatus and Lespedeza cyrtobotrya had higher mean heights on particular soils with different ratios of Trichoderma harzianum and different evenness than others. Some of the plant species did not even survive in some soil treatments of the same soil type but had high mean heights in others as is the case of Dianthus barbatus and Lespedeza cyrtobotrya on Leaf mold soil. Thus the influence of $T$. harzianum to enhance plant growth is dependent on the soil type, $\%$ of the microorganism applied in the soil and the plant species.

The high growth rate of Ivy on Mixed soil $+50 \%$ T. harzianum resulted from the fact that, its initial mean height (Mi) of $17.25 \mathrm{~cm}$ on this soil was small relative to its final mean height $\left(\mathrm{M}_{\mathrm{f}}\right)$ of $40 \mathrm{~cm}$, indicating its initial unfavorable growth on this soil. Contrarily, its initial mean height $\left(\mathrm{M}_{\mathrm{i}}\right)$ on Mixed soil $+100 \%$ T. harzianum was $51.75 \mathrm{~cm}$ which is quite high relative to its final mean height of $87 \mathrm{~cm}$, indicating its consistent favorable growth on this soil. Ivy had high survival rates on these soils. However, Ivy had its highest mean height on Mixed soil + $100 \%$ T. harzianum. Analysis of the plant community showed that, Mixed soil $+100 \%$ T. harzianum consisted of only Ivy and Festuca arundinacea, with Ivy comprising $75 \%$ of the plant community on this soil.

The high growth rate of Festuca arundinacea on Merchantable soil $+50 \%$ Trichoderma harzianum resulted from the fact that, its initial mean height (Mi) of $6.5 \mathrm{~cm}$ on this soil was small relative to its final mean height (Mf) of $18.7 \mathrm{~cm}$, indicating its initial unfavorable growth on this soil. Contrarily, its initial mean height (Mi) on Leaf mold soil $+50 \%$ T. harzianum was $41.79 \mathrm{~cm}$ which is quite high relative to its final mean height of $44.2 \mathrm{~cm}$, indicating its consistent favorable growth on this soil. Also, although $F$. arundinacea had its highest growth rate on Merchantable soil $+50 \%$ T. harzianum, its population was $76 \%$ higher on Leaf mold soil $+50 \%$ T. harzianum than on Merchantable soil $+50 \%$ T. harzianum, indicating a higher competition among $F$. arundinacea species on Leaf mold soil $+50 \%$ T. harzianum due to overcrowding. F. arundinacea had high survival rate and highest mean height on Leaf mold soil $+50 \%$ T. harzianum, $25.5 \mathrm{~cm}$ higher than on Merchantable soil $+50 \% T$. harzianum (Table $1 \&$ Fig. 2). Thus, Leaf mold soil $+50 \%$ T. harzianum provides the best condition to be used as substrate for the revegetation and restoration of rock slopes with $F$. arundinacea.

Dianthus barbatus had its highest mean height, high survival rate and highest growth rate on Leaf mold soil + $100 \%$ T. harzianum. It also had a relatively higher population density on this soil, indicating that this soil provides the best condition to be used as substrate for the revegetation and restoration of rock slopes with $D$. barbatus.

The low survival rate of Lespedeza cyrtobotrya on Leaf mold soil $+50 \%$ T. harzianum (Table 1), was due to the fact that, it had the highest competition from $F$. arundinacea on this soil than on any other soil, since $F$. arundinacea had its highest population, highest mean height and high survival rate on this soil. However, $L$. cyrtobotrya had a high mean height and its highest growth rate on this soil (Fig. $2 \&$ Table 2).

Festuca arundinacea and Ivy were the most favorable species adapted to the area, having higher and viable species population and highest mean heights. Siberian chrysanthemum and Aster koraiensis had the worse results with growth rates of $0 \%$ since all of these plant species died on all soil treatments within a few days. This result is in line with that of Zhong et al., (2009), who suggested the use of herbaceous climbing plants for revegetation of rock slopes, as Ivy (a known climbing plant used in this study), had favorable results. Also, in this study, it was noted that $F$. arundinacea, which is a known grass plant had favorable results and had the most luxuriant growth at all seasons. Restoration of rock slopes could therefore be enhanced with the use of Ivy and $F$. arundinacea since these plants would provide necessary vegetation cover in the area. Vegetation provides habitat and improves landscape aesthetic, thus it plays a major role in quarry restoration (Jim, 2001). Vegetation would also help to enhance slope stability of landscapes

Generally, the plants looked fresher and healthier phenotypically during summer and early autumn seasons with available moisture via rainfall than in late autumn and winter with virtually no rainfall. Thus, rainfall is the main water source for plant growth on rock slopes, so the amount of rainfall falling into artificial holes during any rainfall event is a determining factor for revegetation on rock slopes (Zhong et al., 2009). However, Festuca arundinacea remained relatively fresher in all seasons than the other plants especially during late autumn and winter. Thus, grass plants producing vigorous growth and with extensive root system that helps it withstand drought conditions, are highly adapted on rock slopes, than woody and herbaceous climbing plants. The choice 
of plant species and climate condition are thus imperative considerations for revegetation success (Andres \& Jorda, 2000).

This method of drilling slanted holes on rock slopes was highly successful especially in retaining soil moisture, as the soils in the holes are not completely exposed to direct sunlight, which would have resulted to increase loss of soil moisture via evaporation, and consequently affecting plant survival and growth, as is the case with the method of blasting steep rock slopes. Drilling slanted holes on rock slopes is thus a feasible method of quarry revegetation as these holes could serve in soil deposition and water retention (Zhong et al., 2009), that will further enhance plant growth.

Revegetation would provide habitat and improve landscape beauty and stability, thus ensuring the existence of both animal and plant life on rock slopes. Centipedes, earth worms, insects, and wild plants observed within the plants thus indicate that this method of quarry revegetation enhances plant and animal succession and growth in such degraded landscapes. With $F$. arundinacea already producing seeds on the experimental site, it is evident that after seed dispersal and germination, the plant population will increase.

There is need for further research to be undertaken to investigate the long term growth characteristics of the adapted plants on different slope aspect on rock slopes. Also, since plant roots can penetrate and extend deeper in cracks on natural rocky slopes ( $\mathrm{Li}$ et al., 2007), it is as well necessary to investigate possible long term behavior of plant roots especially with respect to the possibility of the roots enlarging fractures on the rocks.

\section{Conclusion}

The revegetation of steep rock slopes of quarries is a very challenging activity. However, the method of drilling slanted holes on rock slopes is a feasible method to be used for revegetation and restoration of degraded quarries. This will entail a gradual process of demarcating the area into different plots, and engaging the revegetation activity from one plot to another at different intervals. This is because, there is the need for proper follow-up and maintenance of revegetated plants on rock slopes. Different substrates could be used in such revegetation process depending on the target plant species. Considering the experimental site and parameters of growth rate, survival rate, mean length and plant population, Leaf mold soil $+50 \%$ Trichoderma harzianum provide the best conditions for revegetation and restoration of rock slopes with Festuca arundinacea, while Mixed soil $+100 \% T$. harzianum provide the best conditions for revegetation and restoration of rock slopes with Ivy. Drilling slanted holes on rock slopes is therefore a feasible method to be used for revegetation of degraded quarries. Continuous monitoring is imperative on the experimental site so that the population of the experimental plants, wild plants, centipedes, earthworms, insects etc. on the site would be recorded with time.

\section{Acknowledgment}

This work is supported by the Forest Science Technology and Development Grant (No. S211216L020110) funded by the Korea Forest Service.

\section{References}

Adams, P. B. (1990). The potential of mycoparasites for biological control of plant diseases. Ann. Rev. Phytopathol, 28, 59-72. http://dx.doi.org/10.1146/annurev.py.28.090190.000423

Akladious, S. A., \& Abbas, S. M. (2014). Application of Trichoderma harzianum T22 as a biofertilizer potential in maize growth. J. Plant Nutr., 37, 30-49. http://dx.doi.org/10.1080/01904167.2013.829100

Andres, P., \& Jorba, M. (2000). Mitigation strategies in some motorway embankments (Catalonia Spain). Restor. Ecol., 8, 268-275.

Andrews, J. H. (1992). Biological control in the phyllosphere. Ann. Rev. Phytopathol, 30, 603-35. http://dx.doi.org/10.1146/annurev.py.30.090192.003131

Chandra, N. S., Niranjana, S. R., Uday, S. A. C., Niranjan, R. S., Reddy, M. S., Prakash, H. S., Mortensen, C. N. (2008). Seed biopriming with novel strain of Trichoderma harzianum for the control of toxigenic Fusarium verticillioides and fumonisins in maize. Arch. Phytopathol, 43, 264-282. http://dx.doi.org/10.1080/03235400701803879

Chowdappa, P., Mohan, K. S. P., Jyothi, L. M., \& Upreti, K. K. (2013). Growth stimulation and induction of systematic resistance in tomato against early and late blight by Bacillus subtilis OTPB1 or Trichoderma harzianum OTPB3. Biol. Control, 65, 109-117.

Clemente, A. S., Werner, C., Maguas, C., Cabral, M. S., Martins-Loucao, M. A., \& Correia, O. (2004). Restoration of a limestone quarry: effect of soil amendments on the establishment of native Mediterranean 
sclerophyllous shrubs. Restor. Ecol., 12, 20-28. http://dx.doi.org/10.1111/j.1061-2971.2004.00256.x

Elad, Y. (1996). Mechanisms involved in the biological control of Botrytis cinerea incited diseases. Eur. J. Plant Pathol, 102, 719-732.

Ferrigo, D., Raiola, A., Piccolo, E., Scopel, C., \& Causin, R. (2014). Trichoderma harzianum T22 induces in maize systemic resistance against Fusarium verticillioides. J. Plant Pathol, 96, 133-142. http://dx.doi.org/http://dx.doi.org/10.4454/JPP.V9611.038

Hao, Z., \& Chu, L. M. (2011). Plant community structure, soil properties and microbial characteristics in revegetated quarries. Ecol. Eng., 37, 1104-1111. http://dx.doi.org/10.1016/j.ecoleng.2010.05.010

Harman, G. E., \& Bjorkman, T. (1998). Potential and existing uses of Trichoderma and Gliocladium for plant disease control and plant growth enhancement. In: Trichoderma \& Gliocladium (1st Ed.). Taylor \& Francis, UK. 2, 229-265.

Jim, C. Y. (2001). Ecological and landscape rehabilitation of Quarry Site in Hong Kong. Restor. Ecol., 9, 85-94. http://dx.doi.org/10.1046/j.1526-100x.2001.009001085.x

Li, S. C., Sun, H. L., Yang, Z. R., Xiong, W. L., \& Cui, B. S. (2007). Root anchorage of Vitex negundo L. on rocky slopes under different weathering degrees. Ecol. Eng., 30, 27-33. http://dx.doi.org/10.1016/j.ecoleng.2006.11.008

Oliveira, G., Nunes, A., Clemente, A., Correia, O. (2011). Effect of substrate treatments on survival and growth of Mediterranean shrubs in a revegetated quarry: an eight-year study. Ecol. Eng., 37, 255-259. http://dx.doi.org/10.1016/j.ecoleng.2010.11.015.

Vinale, F., Marra, R., Scala, F., Ghisalberti, E., Lorito, M., \& Sivasithamparam, K. (2006). Major secondary metabolites produced by two commercial Trichoderma strains active against different phytopathogens. Lett. Appl. Microbiol, 43, 143-148. http://dx.doi.org/10.1111/j.1472-765X.2006.01939.x

Zammith, L. R., \& Scarano, F. R. (2006). Restoration of a restinga sandy coastal plain in Brazil: survival and growth of planted woody species. Restor. Ecol., 14, 87-94.

Zhong, Q. C., Liang, H. W., \& Ting, T. L. (2009). Revegetation of steep rocky slopes: Planting climbing vegetation species in artificially drilled holes. Ecol. Eng., 35, 1079-1084. http://dx.doi.org/10.1016/j.ecoleng.2009.03.021

Zuoxing, Z., \& Kalidas, S. (1999). Effect of apple pomace-based Trichoderma inoculants on seedling vigour in pea (Pisum satibum) germinated in potting soil. Proc. Bioch., 34, 731-735. http://dx.doi.org/10.1016/S0032-9592(98)00149-6.

\section{Copyrights}

Copyright for this article is retained by the author(s), with first publication rights granted to the journal.

This is an open-access article distributed under the terms and conditions of the Creative Commons Attribution license (http://creativecommons.org/licenses/by/4.0/). 